\title{
Teaching Translocation of Photosynthetic Carbon in Secondary Schools in Trans Nzoia County: Addressing Instructional Challenges
}

\author{
Evans L. Chimoita ${ }^{1, *}$, Mary C.Babu ${ }^{2}$, James A. Barasa ${ }^{3}$, Odundo Paul ${ }^{4}$, Joseph O. Othieno ${ }^{1}$ \\ ${ }^{1}$ Department of Agricultural Economics, University of Nairobi, Kenya \\ ${ }^{2}$ Department of Agricultural Science and Technology, Kenyatta University, Kenya \\ ${ }^{3}$ Department of Mathematics and Science Education, Masinde Muliro University of Science and Technology, Kenya \\ ${ }^{4}$ Department of Education Communications and Technology, University of Nairobi, Kenya
}

Copyright $(2015$ Horizon Research Publishing All rights reserved.

\begin{abstract}
Energy and other environmental conservation measures are emerging issues of concern all over the world. The awareness on climate change and sustainable environmental resource utilization are discussed globally in all sectors of development. This study was conducted to investigate selected Kenyan biology teachers' understanding of photosynthetic carbon translocation and sequestration in ecosystems as an emerging issue. The study sought to relate biology teaching content to a wider scope of energy flow in ecosystem; a subject taught and assessed by teachers of different secondary schools in Kenya. The study employed descriptive survey method. Secondary school agriculture teachers were randomly sampled from secondary schools in one district of Western Kenya. Self-valuation questionnaires were used to capture key information on teachers understanding of photosynthetic carbon and its sequestration as some of the emerging issues in terrestrial ecosystems. Results revealed a rich understanding of green house effects on the general environment among assessed teachers. Majority of the assessed teachers demonstrated clear understanding of carbon dioxide and its contributions to climate changes. However, a high percentage of selected and assessed teachers demonstrated lack of clear grasp on translocation of photosynthetic carbon and its sequestration process from plants into the soil. Furthermore, teachers' demonstrated poor understanding of mitigation of environmental pollution, particularly via Green House Gases (GHGs) control. It was concluded that there was a general knowledge gap among selected agriculture teachers concerning emerging issues particularly in ecology. The study recommended refresher courses to strengthen teachers' competencies in understanding such emerging ecological concepts.
\end{abstract}

Keywords Biology Instructors, Terrestrial Ecosystems, Carbon Translocation, Green House Gases, Secondary Schools

\section{Introduction}

There is limited literature on studies of teachers understanding of fundamental biological concepts such as inheritance, human biology, natural selection, human circulatory system, nutrient cycling in ecosystems [1]. The few available studies show deficiency in knowledge concerning teachers understanding of soil carbon sequestration and carbon trading as emerging issues in ecosystems [13]. Teachers play a very important role in the demystifying formation and disseminating misconceptions among their students [17]. Nonetheless some, studies have suggested that, assessment strategies used by biology teachers influence the development of misconceptions among students. According to Sanders (1993), it is imperative to assess teachers' scope of understanding on a number of biological concepts including carbon sequestration. This is because teachers handle and disseminate bulk information that can positively impact on climate change measures [21].

According to [14], the emerging issues in science and technology play a vital role in national development both in the developed and developing countries. To achieve such efforts, governments must include the current research findings and emerging issues in the school curricula in order to realize various educational reforms in such areas. Carbon dioxide is continually exchanged between aquatic, terrestrial ecosystems and the atmosphere through photosynthesis, respiration and decomposition [3]. According to [12], Kenyan secondary school biology teachers teach photosynthesis concepts based on the syllabus and rarely make further references outside the syllabus. The study revealed that teachers provide explanation of translocation of carbon and various photosynthetic products in leaves, branches, stems and other organs but fail to explain to 
students the fate of organic carbon after translocation, decomposition and respiration in the roots.

According to [13], whereas photosynthesis results in conversion of carbon dioxide into organic carbon in growing plants, decomposition on the other hand releases gaseous back into the atmosphere as a gas. Impounded carbon is also lost through cellular respiration and decomposition of dead plant material increasing leaf litter and shed. The most rapid rate of sequestration into organic materials occurs during early tree growth.

Global warming is believed to be caused by a phenomenon known as the "greenhouse effect," which is an important natural process regulating and maintaining the earth's climate [11]. Rapid increases in the atmospheric levels of carbon dioxide due to human activity such as the burning of fossil fuels and deforestation result in increased amounts of radiant heat trapped near the earth's surface. It is predicted that this interferences gradually increases the mean global temperature, causing dramatic climatic changes and as such, the atmospheric levels of carbon dioxide increases [13]. Teachers across the world should be engaged in these carbon reduction schemes and knowledge training in order to pass the information to students. Information on the amount of carbon soil can store and how each of these and other factors affects this storage should be availed to biology teachers [5]. However, available studies have revealed that knowledge on soil carbon fluxes resulting from management practices have an influence on rhizosphere carbon microclimate contribution to global greenhouse gas reductions [11].

\section{Research Methods}

\subsection{Study Area}

The study was conducted in 36 secondary schools in Trans Nzioa County in Kenya and targeted only trained biology teachers. The study employed descriptive design. In order to obtain the population for agriculture teachers, the study contacted secondary school head teachers. The study sampled two teachers from double streamed schools and one biology teacher from single streamed school, totaling to twenty four biology teachers.

A self-developed valuation questionnaire [24] containing an array of concepts such as photosynthetic carbon, carbon soil sink and sequestration and emerging issues in terrestrial ecosystems were used as a tool to collect data from biology teachers. The data obtained was analyzed using Statistical Package for Social Sciences (SPSS) version 20. Data analysis was then presented using descriptive statistics such as percentages and tables.

\section{Results}

The study sought to test an array of terrestrial photosynthetic carbon issues and concepts indicated as $\mathrm{X}_{1}$ to
$\mathrm{X}_{12}$ in relation to soil carbon sink and sequestration [24] (Appendix 1). Teachers' opinion was rated on basis of teachers' high mastery of concepts, teachers' poor understanding of concepts and teachers lack of ideas concerning tested concepts.

Table 1a. Teachers awareness and understanding of new concepts in ecosystems

\begin{tabular}{|c|c|c|c|}
\hline \multirow{2}{*}{ Concept Statement } & \multicolumn{3}{|c|}{ Percentage rating } \\
\cline { 2 - 4 } & $\mathrm{A} \%$ & $\mathrm{R} \%$ & $\mathrm{~N} \%$ \\
\hline $\begin{array}{c}\text { Teachers understanding of soil carbon } \\
\text { dynamics }\left(\mathrm{x}_{1}\right)\end{array}$ & 29 & 38 & 33 \\
\hline $\begin{array}{c}\text { Accumulation of carbon in soil has impact } \\
\text { on soil ecosystem }\left(\mathrm{x}_{2}\right)\end{array}$ & 29 & 17 & 54 \\
\hline $\begin{array}{c}\text { Teachers support of plant to soil carbon } \\
\text { flow hypothesis }\left(\mathrm{x}_{3}\right)\end{array}$ & 25 & 33 & 41 \\
\hline
\end{tabular}

$\mathrm{N}=24$; Opinion rating: A: Accepted

R: Rejected N: No Response

There was conflicting opinion expressed among teachers' concerning understanding of the new concepts in ecosystems in terms of rating, particularly in regard to general soil dynamics (Table $1 \mathrm{~b}$ ). Similar trend in conflicting responses was displayed (Table 1c). Further, majority 54\% teachers (X2) teachers had no idea as to whether there was accumulation of carbon in soil, which had impact on soil ecosystem like microbial population or not.

Table 1b. Teachers degree of understanding of cross cutting concepts in ecosystems

\begin{tabular}{|c|c|c|c|}
\hline \multirow{2}{*}{ Concept Statement } & \multicolumn{3}{|c|}{ Percentage rating } \\
\cline { 2 - 4 } & $\mathrm{A} \%$ & $\mathrm{R} \%$ & $\mathrm{~N} \%$ \\
\hline $\begin{array}{c}\text { Clearing of old plant growth and native } \\
\text { forests reduce carbon accumulation in the } \\
\text { soil }\left(\mathrm{X}_{4}\right)\end{array}$ & 29 & 33 & 38 \\
\hline $\begin{array}{c}\text { Afforestation and reforestation offset } \\
\text { greenhouse effect }\left(\mathrm{X}_{5}\right)\end{array}$ & 71 & 29 & 0 \\
\hline $\begin{array}{c}\text { Rapid wholesale of carbon pollution will } \\
\text { reduce ecosystems }\left(\mathrm{X}_{6}\right)\end{array}$ & 25 & 46 & 29 \\
\hline
\end{tabular}

$\mathrm{N}=24$; Opinion rating Legend: A: Accepted

R: Rejected N: No Response

Table 1c. Teachers' understanding of greenhouse effects on ecosystems

\begin{tabular}{|c|c|c|c|}
\hline \multirow{2}{*}{ Concept Statement } & \multicolumn{3}{|c|}{ Percentage rating } \\
\cline { 2 - 4 } & $\mathrm{A} \%$ & $\mathrm{R} \%$ & $\mathrm{~N} \%$ \\
\hline $\begin{array}{c}\text { Carbon pollution will decline by } 5 \% \text { by } \\
\text { year 2030 }\left(\mathrm{x}_{7}\right)\end{array}$ & 8 & 54 & 24 \\
\hline $\begin{array}{c}\text { Excess sink of photosynthetic carbon in } \\
\text { soil can cause micro-climatic change } \\
\text { and invasion by alien species }\left(\mathrm{x}_{8}\right)\end{array}$ & 62 & 8 & 29 \\
\hline Trees reduce greenhouse effects $\left(\mathrm{x}_{9}\right)$ & 71 & 29 & 0 \\
\hline
\end{tabular}

$\mathrm{N}=24$; Opinion rating Legend: A: Accepted

R: Rejected N: No Response

Results in (Tables 1c and Table 1d) revealed conflicting and inconsistent results from teachers assessed, despite the concepts tested being related. There was similarities in the trends in terms of percentage among teachers understanding of soil carbon dynamics $29 \%\left(\mathrm{X}_{1}\right)$, and concepts which stated that clearing of old plant growth and native forests reduce carbon accumulation in soil $29 \%\left(\mathrm{X}_{4}\right)$ in Table 1c, and $29 \%$ carbon pollution will decline by $5 \%$ by 2030 (X7) (Table 1d). 
In another category $\left(\mathrm{X}_{3}\right), 25 \%$ teachers supported plant-soil carbon flow hypothesis and $\left(\mathrm{X}_{6}\right) 25 \%$ teachers the supported fact that rapid wholesale carbon pollution will reduce ecosystem dynamics. Contrary, majority of $29 \%$ rejected facts that $\left(\mathrm{X}_{9}\right)$ trees reduce greenhouse effects and(X12) there was common understanding between plant activity and microbial actions.

Table 1d. Teachers' opinion of organic carbon on soil ecosystems

\begin{tabular}{|c|c|c|c|}
\hline \multirow{2}{*}{ Concept Statement } & \multicolumn{3}{|c|}{ Percentage rating } \\
\cline { 2 - 4 } & $\mathrm{A} \%$ & $\mathrm{R} \%$ & $\mathrm{~N} \%$ \\
\hline $\begin{array}{c}\text { There is a relationship between } \\
\text { photosynthesis and soils in terms of } \\
\left.\text { microbial activities ( } \mathrm{x}_{10}\right)\end{array}$ & 58 & 8 & 33 \\
\hline $\begin{array}{c}\text { Microbial activity affects positively soil } \\
\left.\text { ecosystem and soil nutrient status ( } \mathrm{x}_{11}\right)\end{array}$ & 71 & 29 & 0 \\
\hline $\begin{array}{c}\text { There is link between plant activity and } \\
\left.\text { microbial actions ( } \mathrm{x}_{12}\right)\end{array}$ & 33 & 29 & 38 \\
\hline
\end{tabular}

$\mathrm{N}=24$; Opinion rating: A: Accepted

R: Rejected N: No Response

\section{Discussion}

In relation to Table 1a, there was a common understanding of concepts among the teachers that afforestation and reforestation offset greenhouse effect (71\%). Contrary, teachers could not relate ideas in $\left(\mathrm{X}_{6}\right)$, that rapid wholesale of carbon pollution would reduce ecosystems dynamics $(21 \%)$. In related study, lack of exposure to current trends in ecosystems and inexperience or deficiencies in quest for new knowledge in ecology, results to poor understanding of concepts in ecosystems [12]. Indeed previous works have demonstrated that teachers play a strong direct role in the formation of misconceptions held by their students [17] and [23].

Further, teachers' demonstrated weak understanding on accumulation of carbon in the soil and its impact on soil ecosystem $\left(\mathrm{X}_{3}\right)$ and microbial activity affects soil ecosystem and soil nutrients. Teachers' expressed unclear opinion rating that there is plant-soil carbon flow hypothesis (X3) and that $\left(\mathrm{X}_{12}\right)$ there is a possible link between in plant activity and microbial actions. It is common knowledge that climate change is taking place. Green-house gas levels are rising and are now at their highest concentration for more than 400,000 years, [7].

Climate changes impacts on biodiversity are already evident by shifting and migration changes of insects, animals, modified flowering and fruiting cycles, species extinction, drought, flood induced die back and invasion of new species as obvious indicators of hypothesis (X8) [5]. Concepts relating to opinions $\mathrm{X} 1, \mathrm{X} 4, \mathrm{X} 7$ and $\mathrm{X} 10$ in (Tables 1b, 1c, 1d) had majority of teachers' stating common understanding.

Explanation supporting increased input of carbon to soil and influences on soil organic matter processes and micro-organic was clear among teachers as depicted in (X11), where teachers were able to commend on microbial activity affecting soil ecosystem and soil nutrient status. Majority of teachers $(71 \%)$ concurred that the amount and activities of soil micro-organisms may change $\left(\mathrm{X}_{9}\right)$, which may accelerate nutrients mineralization in soil and increase plant nutrients supply. Further, changes in litter components may also increase biota, particularly the amount and activity of hetero-nutritional bacteria. Concerning whether there was existence of concept $\left(\mathrm{X}_{12}\right)$; that, there was across talk between plant actively and microbial actions; a notable number of teachers gave conflicting information as indicated in Table $1 \mathrm{~d}$.

In a similar study in Turkey, it was revealed that regardless of age and level of schooling, misconception is prevalent in understanding and interpreting biological concepts; including University graduates [6], [15] and [20].

Carbon stored in soil body may increase, which makes soil potential sink for carbon. This will possibly mitigate the increase of carbon dioxide in the atmosphere. Explanation supporting increased input of carbon to soil and influences on soil organic matter processes and micro-organic was clear among teachers as depicted in $\left(\mathrm{X}_{11}\right)$, where teachers were able to commend whether microbial activity affects soil ecosystem and soil nutrients. These effects could be a result of increased soil organic matter carbon fluxes, which have been suggested to result from the interaction of elevated $\mathrm{CO}_{2}$ concentrations and elevated temperature [4] and [22].

Majority of teachers (70\%) concurred that the amount and activities of soil micro-organisms may change $\left(\mathrm{X}_{9}\right)$, which may accelerate nutrients mineralization in soil and increase plant nutrients supply. Further, the changes in litter components may also increase biota, particularly the amount and activity of hetero-nutritional bacteria.

On comparison on whether there was hypothesis $\left(\mathrm{X}_{12}\right)$; across talk between plant actively and microbial actions, many of the respondents gave conflicting information as indicated in Table 1d. The few examples we used in current research serve to demonstrate the inherent complexity in soil carbon science. For instance, although greater productivity above ground mostly translates into higher soil carbon inputs, such input of fresh labile (easily decomposable) carbon has the potential of stimulating decomposition of older, recalcitrant (difficult to decompose) soil carbon[ 8], [9], thereby decreasing overall soil carbon stocks. In another example of the interrelatedness of factors affecting soil carbon, the overall trend in global soil carbon respiration rates has been an increase in respiration with increasing temperature; however, it is unclear if that trend is offset by higher inputs from higher productivity [2].

Carbon is likely to be sequestered in lands converted from agriculture to forests and in existing forests in temperate zones [16], such as U.S. Northeastern forests [10], quantification of soil carbon dynamics remain problematic. All these concerns then make it difficult to specifically say that teachers lack the understanding of the concept. In any case, their background trainings, particularly the books used during their training have a lot of bearing. The previous work suggests that another factor that contributes to the occurrence of misconceptions by students is textbooks, which include many errors and incorrect information [19]. 


\section{Conclusions}

Results revealed a rich understanding of green house effects on the general environment among assessed biology teachers. Majority of the teachers demonstrated clear understanding of carbon dioxide and its contributions to climate changes. However, a high percentage of selected and assessed teachers demonstrated lack of clear grasp on translocation of photosynthetic carbon and its sequestration process from plants into the soil. Furthermore, teachers' demonstrated weak understanding of carbon translocation and mitigation of environmental pollution, particularly via Green House Gases (GHGs) management. It was concluded that there was a general knowledge gap among selected biology teachers concerning emerging issues particularly in ecology. The study recommended refresher courses to strengthen teachers' competencies in understanding such emerging ecological concepts.

\section{Appendix}

\section{Questionnaire}

Express your opinion by ticking against AGREE, DISAGREE and NO IDEA options attached to concepts below, to express your degree of understanding of ecosystems concepts below.

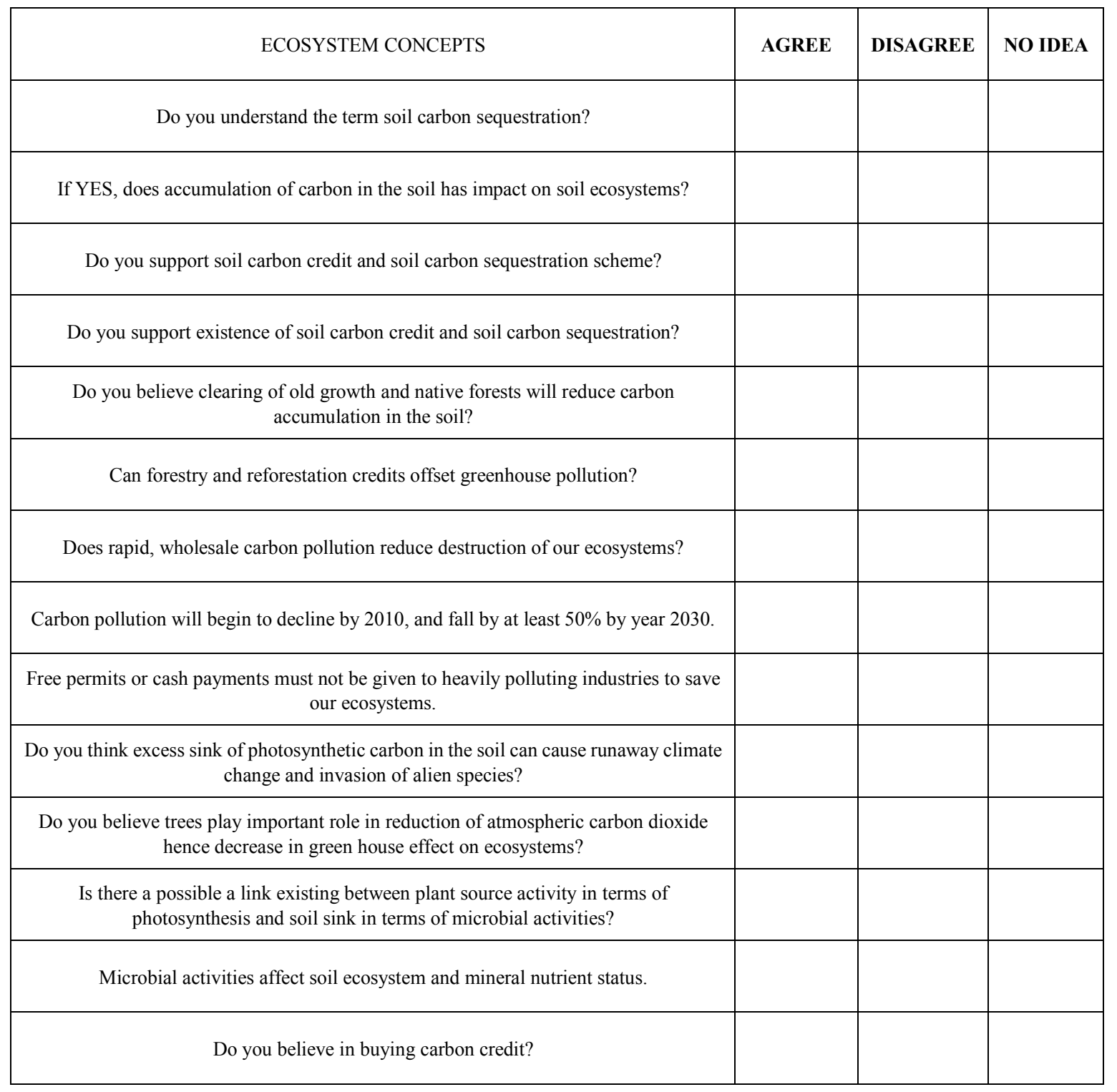




\section{REFERENCES}

[1] Adeniyi, E. (1985). Misconcemptions of selected ecological concepts held by some Nigerian students. Journal of Biological Education, 19, p.311-316.

[2] Bond-Lamberty, B., Thomson, A. (2010) Temperature-associated increases in the global soil respiration record. Nature, 464, p.579-582

[3] Brown, S., Hall, C., Knabe, R., Trexler, W., \& Woomer, P. (1993). Tropical Forests: Their past, present and future role in the terrestrial carborn budget. Water, Air, Soil Pollution, p. 71-94.

[4] Butnor, J., Johnsen, K., Oren, R., Katul, G. (2003). Reduction of forest floor respiration by fertilization on both carbon dioxide-enriched and reference 17-year-old loblolly pine stands. Global Change Biology, 9, p.849-861

[5] Campbell, B. (2010, October 13). The united nations food agenda and farming research groups in helping farmers cut carbon emmissions. The Standard Newspaper Daily, 11980, p.20.

[6] Capa, Y. (2000). An analysis of 9th grade student's miseoneeptions concerning photosynthesis and respiration in plants. Master's Thesis, Middle East Technical University, Ankara.

[7] Carbon Fund. (2003). Carbon Sequestration: Developing forest accounting principles that are effective and sequestrate carbon and improve biodiversity. Retrieved October 2012, http://www.thecarbonfund.org

[8] Cheng, W., Johnson, D. (2003). Rhizosphere Effects on Decomposition: Controls of Plant Species and Fertilization. Journal Soil Science, 67, p.1418-1427.

[9] Fontaine, S., Barot, S., Barre, P., Bdioui, N., Mary, B.,Rumpel., C. (2007). Stability of organic carbon in deep soil layers controlled by fresh carbon supply. Nature, 450, p.277-280

[10] Goulden, M.,Munger., W., Fan, M, Daube, C., Wofsy, C. (1996) Measurements of carbon sequestration by long-term eddy covariance: methods and a critical evaluation of accuracy. Global Change Biology, 2, 169-182.

[11] Karani, P. (2004). Afforestation, reforestation and forest management: Natural Resource Conservation, Management and Carbon Sequestration within the Scheme of Payment for

Environmental Services (PES): Bureau of Environmental Analysis International (BEA-International). Retrieved October 2012 www.IBEA.org

[12] .Khatete, D. (1995). Children's Understanding of Decomposition and its Importance in Nature Among some Kenyan Children. Journal of Biological Education,45, p.311-316.

[13] Llyas, K. (2011, October 14 ). Are we Ready for Carbon Trading? Internationally, Carbon Trading has become a Money Spinner. The Daily Standard Newspaper, 11980, p.48. Nairobi.

[14] Osborne, J., \& Simon, S. (2003). Attitudes Towards science: a Review of Literature and its Implications. International Journal of Science Education, 35(4), P.1049-1079.

[15] Ozkan, O. (2001). Remediation of seventh grade students' misconceptions related to ecology concepts through conceptual change text approach. Journal of Biological Education,55, p.411-416.

[16] Post, M., Kwon, C. (2000) Soil carbon sequestration and land-use change: processes and potential. Global Change Biology, 6(2), 317-327.

[17] Sanders, M. (1993). Erroneous ideas about respiration: The teacher factor. Journal of Research in Science Teaching, 30(8), p.919-934.

[18] Storey, D.(1991). Textbook errors and misconceptions in biology: cell metabolism. American Biology Teacher, 53(6) p.339-343.

[19] Storey, D.(1992). Textbook errors and misconceptions in biology: American Biology Teacher, 54(3), p.161-166.

[20] Sungur, S., Tekkaya, C., \& Geban, O. (2001). The contribution of conceptual change texts accompanied by concept mapping to students' understanding of the human circulatory system". Journal of School Science and Mathematics 11 (2), p.91-101.

[21] Ugulu, J., Aydin, H., Yorek, N., and Dogan, N. (2008). The impact of endemism concept on environmental attitudes of secondary school students. Natural Sciences, 7, 165-173.

[22] Tingey, T., Lee, H.,Waschmann, R, Johnson, G., Rygiewic., T. (2006). Does soil carbon dioxide efflux acclimatize to elevated temperature and carbon dioxide during long-term treatment of douglas-fir seedlings? New Phytologist, 170, p.107-118.

[23] Yip, Y. (1998). Teachers' misconceptions of the circulatory system Journal of Biological Education. 32(3), p.207-21 